\title{
Taste preference of Chlorella sp. algae from dairy wastewater by weaned dairy calves
}

\author{
S. C. Luzzi, ${ }^{1}$ R. D. Gardner, ${ }^{1 *}$ and B. J. Heins ${ }^{2}+\odot$
}

\section{Graphical Abstract}

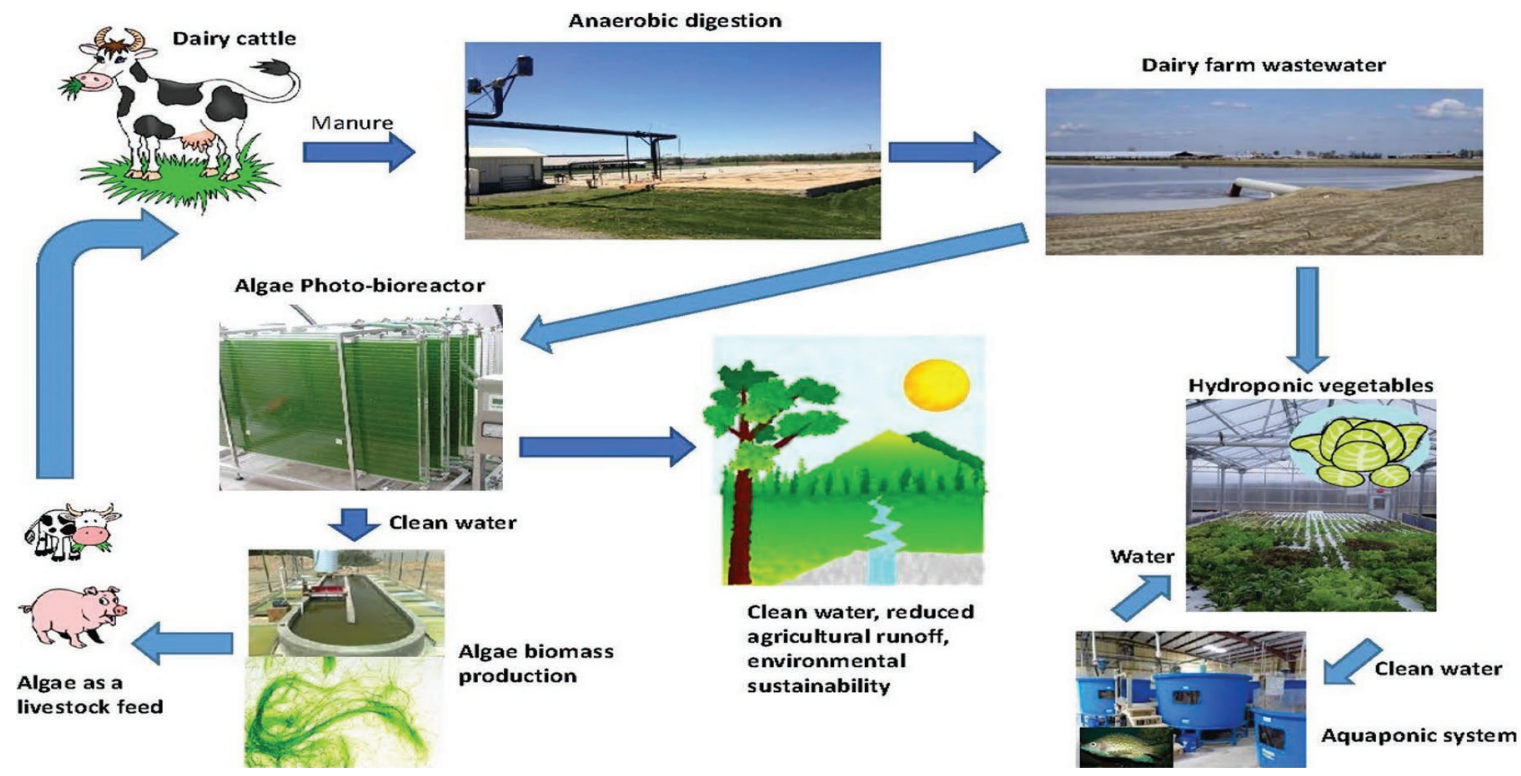

\section{Summary}

Nutrient removal, in particular nitrogen and phosphorus, from wastewater is a growing regulatory need, and the use of microalgae may create a unique amalgamation between dairy wastewater treatment and livestock feed production. The current study evaluated the taste preference of specific amounts of algae produced from dairy wastewater on preference of heifer calves. An integrated facility can utilize and recycle nutrients from dairy farm wastewater, as well as carbon dioxide emissions on-site, to simultaneously produce "green" energy, clean water, food, and livestock feed.

\section{Highlights}

- Microalgae has been used as a nutrition source by humans for thousands of years

- We evaluated taste preference of Chlorella sp. fed to dairy calves

- Microalgae may be added to calf starter without any adverse effects

- Calves prefer calf starter without microalgae

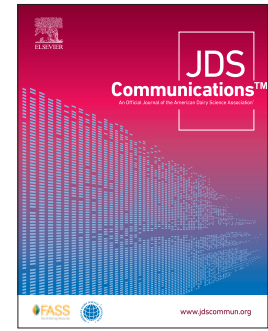

\footnotetext{
${ }^{1}$ Department of Bioproducts and Biosystems Engineering, University of Minnesota, St. Paul 55108, ${ }^{2}$ Department of Animal Science, University of Minnesota, St. Paul 55108. *Dr. Gardner contributed to this research before he passed away. +Corresponding author: hein0106@umn.edu. $\odot$ 2020, The Authors. Published by Elsevier Inc. and Fass Inc. on behalf of the American Dairy Science Association ${ }^{\circledast}$. This is an open access article under the CC BY license (http:// creativecommons.org/licenses/by/4.0/). Received June 19, 2020. Accepted September 17, 2020.
} 


\title{
Taste preference of Chlorella sp. algae from dairy wastewater by weaned dairy calves
}

\author{
S. C. Luzzi, ${ }^{1}$ R. D. Gardner, ${ }^{1 *}$ and B. J. Heins ${ }^{2} \dagger \odot$
}

\begin{abstract}
The objective of this study was to evaluate the taste preference of calves fed Chlorella sp. microalgae produced from dairy lagoon wastewater. Six Holstein dairy heifer calves that were 12 to $14 \mathrm{wk}$ of age (107 $\pm 3.8 \mathrm{~kg}$ of body weight) were fed 0 (control), 30 , or $60 \mathrm{~g}$ of Chlorella sp. daily, and all calves were fed all treatments in a sequential elimination study. For the 7-d experiment, $\mathrm{d} 1$ to 2 were for diet adaptation and d 3 to 4 were for data collection. During the final $3 \mathrm{~d}$, the primary consumed treatment was removed to determine the second preferred treatment. Calves were ranked for total intake from the consumption of all treatments. The microalgae product used in this study was isolated from dairy wastewater lagoon, and microalgae biomass was produced using outdoor hanging bag bioreactors with Chlorella sp. to recycle the wastewater. The biomass was sterilized and kept frozen at $-4^{\circ} \mathrm{C}$ until fed to calves. Calves were housed individually in hutches with outdoor access under solar panels, with free-choice water. Calves consumed more dry matter from control calf starter $(3.4 \mathrm{~kg} / \mathrm{d})$ than from the starter with $30 \mathrm{~g}(2.42 \mathrm{~kg} / \mathrm{d})$ or $60 \mathrm{~g}(1.56 \mathrm{~kg} / \mathrm{d})$ of microalgae during the first 2-d period. During the second 2-d period (d 3 and 4), dry matter intake was reduced for the $60 \mathrm{~g} / \mathrm{d}$ microalgae starter compared with the control and $30 \mathrm{~g} / \mathrm{d}$ microalgae starters. Five of 6 calves in this study always ranked the control treatment first when given a choice and ranked the $30 \mathrm{~g}$ of microalgae starter second choice. Results indicated that microalgae may be added to calf starter; however, calves preferred calf starter without microalgae.
\end{abstract}

M icroalgae has been used as a nutrition source by humans for thousands of years. However, large-scale production of algae has increased over the last few decades (Görs et al., 2010). For animal feeding, microalgae can provide protein, vitamins, minerals, carbohydrate, and fatty acids, which is a difficult combination to find in the same organism (Kotrbáček et al., 2015; Makkar et al., 2016; Madeira et al., 2017). Algae may provide an alternative feedstuff for the ruminant dairy calf market.

In this study, we used Chlorella sp. to recycle nutrients from a dairy wastewater lagoon at the University of Minnesota West Central Research and Outreach Center (WCROC; Morris, MN) and to produce high-quality microalgae biomass to evaluate taste preference in dairy calves. This was a comprehensive nutrient cycling study, in which treated dairy wastewater was recycled back to the environment without harmful effects and provided nutrients from microalgae for feeding supplementation of cattle.

Previous taste preference studies have evaluated alternative types of microalgae and macroalgae (Kuzmaite et al., 2009; Erickson et al., 2012; Heins and Chester-Jones, 2015; Jeon et al., 2016; Schimek et al., 2016). However, an integrated system to produce microalgae isolated from a dairy wastewater lagoon and to evaluate the microalgae as a livestock feed has not been studied. The hypothesis of this study was that feeding Chlorella sp. in calf starter to dairy calves would not affect feed intake and taste preference compared with control calf starter. Therefore, our objective was to produce a microalgae feed supplement and evaluate the taste preference of microalgae added to calf starter in a sequential elimination study.

Chlorella sp. were isolated from the dairy wastewater lagoon at the University of Minnesota West Central Research and Outreach
Center. The microalgae biomass was produced using a hanging bag photobioreactor (Koller, 2015) to recycle the dairy wastewater from the dairy lagoon. The bioreactor was constructed with treated wood $(1.73 \mathrm{~m}$ high $\times 2.06 \mathrm{~m}$ long $\times 1.22 \mathrm{~m}$ wide $)$ with 3 flexible metal bars ( $5 \mathrm{~mm}$ in diameter and $1.34 \mathrm{~m}$ high) that were $0.3 \mathrm{~m}$ apart to support the shape of the hanging bags. Plastic tubes (15 $\mathrm{mm}$ in diameter and $1.33 \mathrm{~m}$ high $\times 0.52 \mathrm{~m}$ long) were used to supply oxygen and carbon dioxide to the bags when needed. Each plastic tube had 12 holes ( $0.5 \mathrm{~mm}$ in diameter) for aeration.

The Chlorella sp. were harvested weekly from the photobioreactors and autoclaved and sterilized at $121^{\circ} \mathrm{C}$ for $30 \mathrm{~min}$ to prevent any bacteria from being fed to calves. After sterilization, the biomass was frozen at $-20^{\circ} \mathrm{C}$ until the start of the feeding study.

The microalgae were analyzed for the mycotoxins aflatoxin, vomitoxin, fumonisin, ochratoxin, T-2 toxin, and zearalenone, as well as the heavy metals arsenic, mercury, cadmium, lead, and antimony at Midwest Laboratories (Omaha, NE) to determine safety before the beginning of the experiment. Mycotoxins were analyzed using method 2008.02 (AOAC International, 2016) and heavy metals were analyzed following EPA 6010 (US EPA, 2014) and EPA 7471 (Campisano et al., 2017) methods. Detected concentrations were as follows: aflatoxin $<1.0 \mu \mathrm{g} / \mathrm{kg}$, vomitoxin $<0.1$ $\mathrm{mg} / \mathrm{kg}$, fumonisin $<0.1 \mathrm{mg} / \mathrm{kg}$, ochratoxin $<1.0 \mu \mathrm{g} / \mathrm{kg}$, T-2 toxin $<0.1 \mathrm{mg} / \mathrm{kg}$, zearalenone $<50 \mathrm{mg} / \mathrm{kg}$, arsenic $10.4 \mathrm{mg} / \mathrm{kg}$, mercury $<0.1 \mathrm{mg} / \mathrm{kg}$, cadmium $<0.5 \mathrm{mg} / \mathrm{kg}$, lead $<5.0 \mathrm{mg} / \mathrm{kg}$, and antimony $<10 \mathrm{mg} / \mathrm{kg}$. All levels of mycotoxin and heavy metals were below the maximum concentrations recommended for livestock. Nutrient analysis of Chlorella sp. and calf starter was conducted by Rock River Laboratory Inc. (Watertown, WI). Calf starters were analyzed using AOAC International (2016) methods for CP (method

\footnotetext{
${ }^{1}$ Department of Bioproducts and Biosystems Engineering, University of Minnesota, St. Paul 55108, ${ }^{2}$ Department of Animal Science, University of Minnesota, St. Paul 55108. *Dr. Gardner contributed to this research before he passed away. +Corresponding author: hein0106@umn.edu. $\odot$ 2020, The Authors. Published by Elsevier Inc. and Fass Inc. on behalf of the American Dairy Science Association ${ }^{\circledast}$. This is an open access article under the CC BY license (http:// creativecommons.org/licenses/by/4.0/). Received June 19, 2020. Accepted September 17, 2020.
} 
Table 1. Nutrient composition (\% of DM unless otherwise noted) of Chlorella sp. and calf starters offered to calves

\begin{tabular}{lcccc}
\hline & & \multicolumn{3}{c}{ Calf starter } \\
\cline { 3 - 5 } Nutrient & Chlorella sp. & Control & $30 \mathrm{~g} / \mathrm{d}$ of algae & $60 \mathrm{~g} / \mathrm{d}$ of algae \\
\hline CP & 49.2 & 18.6 & 18.9 & 20.5 \\
Fat & 2.3 & 6.9 & 6.4 & 6.9 \\
Starch & 38.5 & 47.1 & 43.4 & 40.5 \\
NDF & 32.8 & 12.5 & 14.6 & 12.9 \\
ADF & 11.6 & 7.7 & 5.5 & 5.2 \\
Ash & 9.9 & 7.6 & 6.6 & 1.2 \\
Calcium & 1.2 & 0.9 & 0.9 & 0.6 \\
Phosphorus & 1.7 & 0.5 & 0.6 & 0.9 \\
Potassium & 1.1 & 0.8 & 0.8 & - \\
Magnesium & 0.5 & 0.2 & 0.2 & - \\
TDN & 71.6 & - & - & - \\
Digestible energy, Mcal/kg & 3.1 & - & - & - \\
ME, Mcal/kg & 2.7 & - & - & - \\
Sodium & 0.5 & - & - & - \\
Iron, $\mathrm{mg} / \mathrm{kg}$ & 5,020 & - & - & \\
Zinc, mg/kg & 46 & - & & - \\
\hline
\end{tabular}

990.03), ether extract (method 920.39), starch (method 996.11), NDF (method 2002.04), ADF (method 973.18), and ash (method 942.05); mineral composition was determined by wet chemistry and inductively coupled plasma (method 2015.01).

All animal care and management for the study was approved by the University of Minnesota Institutional Animal Care and Use Committee (Animal Subjects Code \#1709-35098A). Six Holstein weaned heifer calves that ranged in age from 12 to 14 wk (106.71 $\pm 3.81 \mathrm{~kg}$ of $\mathrm{BW})$ of age were enrolled to test the preference for control starter or starters containing 30 or $60 \mathrm{~g} / \mathrm{d}$ of Chlorella sp. The Chlorella sp. was added to the texturized calf starter and mixed by hand. The experiment was conducted during the same time period for all 6 calves. Calves were individually housed in hutches (CalfTel, Germantown, WI; $2.12 \mathrm{~m} \times 1.14 \mathrm{~m} \times 1.22 \mathrm{~m}$ ) with outdoor access $\left(17.98 \mathrm{~m}^{2}\right)$ under solar photovoltaic panels for shade ( $3 \mathrm{~m}$ above the ground) with free-choice water. Calves were bedded with pinewood shavings.

Every morning for $7 \mathrm{~d}$, feed and orts were weighed and recorded. Five buckets in total ( $28 \mathrm{~cm}$ in diameter and $21 \mathrm{~cm}$ high) were placed outside the hutches within the pen. Three buckets containing the calf starter were placed in the pen, and two empty buckets were used on the edge to nullify border effects. The treatments in each bucket were randomized each day during the experiment. All 3 treatments were offered for $7 \mathrm{~d}$, with the first $2 \mathrm{~d}$ for diet adaptation (period 1) and d 3 and 4 for data collection (period 2). After $\mathrm{d} 4$, the treatment with the overall greatest consumption was removed and replaced with an empty bucket. The last $3 \mathrm{~d}$ were used to determine the second preference. Nutrient composition for the microalgae and calf starter are given in Table 1.

For statistical analysis of DMI, the fixed effects were calf starter treatment, and calf was a random effect. The MIXED procedure (SAS Institute, 2016) was used to obtain solutions and conduct the ANOVA. Individual calf was the experimental unit. All treatment results are reported as least squares means, with significance declared at $P<0.05$. Kendall's coefficient of concordance was calculated to rank the consumption of the treatments from most to least preferred (Nombekela et al., 1994) using JMP 14.3 software (SAS Institute Inc., Cary, NC).

The total mean DMI for d 1 and 2, d 3 and 4, and for the 7-d period of the study by treatment group are given in Table 2 . During the 2-d adaptation period, calves consumed more $(P<0.05)$ of the control starter, followed by the starter with $30 \mathrm{~g}$ of algae and that with $60 \mathrm{~g}$ of algae. Mean DMI did not differ $(P>0.05)$ for treatment groups on $\mathrm{d} 3$ and 4 of the study or for the total 7-d duration. During the first period of the study, calves averaged $1.23 \pm 0.24 \mathrm{~kg}$ of DM/d. Calves had mean DMI of $1.32 \pm 0.15 \mathrm{~kg}$ for the second period and $1.26 \pm 0.16 \mathrm{~kg}$ for the third period. The mean DMI for each period indicated that DMI was not affected by removal of the most preferred calf starter. Daily DMI were typical for heifer calves from 12 to $14 \mathrm{wk}$ of age (Kienitz et al., 2017).

For preference of algae calf starters, the control starter ranked first on 6 calf days, followed by the starter with $30 \mathrm{~g}$ of algae (ranked first on $4 \mathrm{~d}$ ) and that with $60 \mathrm{~g}$ of algae (ranked first on 2 d). Calves ranked the control starter as first preference followed by

Table 2. Mean total DMI (kg) consumed for each calf starter treatment in each feeding period

\begin{tabular}{|c|c|c|c|c|c|c|}
\hline \multirow[b]{3}{*}{ Variable } & \multicolumn{6}{|c|}{ Treatment } \\
\hline & \multicolumn{2}{|c|}{ Control } & \multicolumn{2}{|c|}{$30 \mathrm{~g} / \mathrm{d}$ of algae } & \multicolumn{2}{|c|}{$60 \mathrm{~g} / \mathrm{d}$ of algae } \\
\hline & Mean & SE & Mean & SE & Mean & SE \\
\hline Day 1 and 2 & $3.4^{\mathrm{a}}$ & 0.34 & $2.4^{\mathrm{ab}}$ & 0.34 & $1.6^{b}$ & 0.34 \\
\hline Day 3 and 4 & 2.9 & 0.31 & 2.9 & 0.31 & 2.2 & 0.31 \\
\hline Day 1 to 7 & 10.6 & 1.2 & 8.1 & 1.2 & 7.9 & 1.2 \\
\hline
\end{tabular}

a,b Means within a row without common superscripts are different at $P<0.05$. 
Table 3. Ranking of treatments (mean and SE) for the $d 3$ and 4 and $d 1$ to 7 feeding periods

\begin{tabular}{lccc}
\hline & \multicolumn{3}{c}{ Treatment } \\
\cline { 2 - 4 } Variable & Control & $30 \mathrm{~g} / \mathrm{d}$ of algae & $60 \mathrm{~g} / \mathrm{d}$ of algae \\
\hline $\begin{array}{l}\text { Day } 3 \text { and } 4 \\
\text { Total days chosen }\end{array}$ & 6 & 4 & 2 \\
Mean and SE & $1.00^{\mathrm{a}} \pm 0.32$ & $0.67^{\mathrm{a}} \pm 0.32$ & $0.33^{\mathrm{b}} \pm 0.32$ \\
$\begin{array}{l}\text { Day } 1 \text { to } 7 \\
\text { Mean and } \mathrm{SE}^{3}\end{array}$ & $1.67 \pm 0.35$ & $2.17 \pm 0.35$ & $2.17 \pm 0.35$ \\
\hline
\end{tabular}

a,b Means within a row without common superscripts are different at $P<0.05$.

${ }^{1}$ Number of days a specific treatment was chosen as first preference by heifers for $d 3$ and 4 ( 6 heifers $\times 2 d=12$ total days).

${ }^{2}$ Mean $( \pm$ SE) number of days a treatment was chosen per heifer.

${ }^{3}$ Rank of treatments: 1 = most preferred and 3 = least preferred.

the starter with $30 \mathrm{~g}$ of algae. Kendall's coefficient of concordance was 0.12 for the control, indicating that the calves preferred the control starter over that with $60 \mathrm{~g}$ of algae.

The overall ranking of treatments is shown in Table 3. The control starter was preferred based on DMI across the 7-d study period. Five of 6 calves in this study always ranked the control treatment first when given a choice and ranked the starter with 30 $\mathrm{g}$ of microalgae second. However, there was no significant difference in rank across the total $7 \mathrm{~d}$ of the study for the control, $30 \mathrm{~g} / \mathrm{d}$ algae, and $60 \mathrm{~g} / \mathrm{d}$ algae calf starters for taste preference of calves.

The purpose of this study was to determine whether microalgae grown from dairy wastewater on farm could be used to supplement calf starter. In the current study, calves preferred calf starter that did not include microalgae that was high in protein, starch, and ash. Erickson et al. (2012) and Heins and Chester-Jones (2015) reported that calves mainly preferred calf starter without the addition of kelp, and calves preferred control calf starter. Kelp was not desirable in those studies because of its palatability when calves consumed greater amounts of calf starter with greater amounts of kelp. Possibly, the microalgae in the current study had a similar effect to kelp, and calves reduced their intake of calf starter with 60 $\mathrm{g}$ of algae because of reduced palatability. Calves prefer a sweet, molasses flavor in calf starter (Nombekela et al., 1994), and the addition of microalgae may have resulted in an off-flavor and smell that reduced intake of this calf starter with microalgae. Chapman et al. (2016) reported that calves preferred control calf starter compared with calf starter with addition of cinnamaldehyde; the DMI of calves may have been affected by diet interactions with cinnamaldehyde essential oil, and the rumen microbiome may adapt differently to alternative feed supplements.

The microalgae cellulosic cell wall is rigid and difficult to digest, which may explain in part why substituting part or all of cattle diets with microalgae may be difficult (Kotrbáček et al., 2015). Digestibility improved with a mixture of Chlorella sp. and Scenedesmus sp. added to the diet of milk-fed calves at $10 \%$ of BW compared with sesame seed oil (Chowdhury et al., 1995). Furthermore, the higher ash content of calf starter with added Chlorella sp. may have affected palatability and reduced intake of calf starter with the microalgae. Recently, Altomonte et al. (2018) reported that microalgae supplementation in the diets of cattle reduced DMI and milk and fat production. Reduced intake of calf starter with microalgae may be caused by decreased fiber digestibility; also, fermentation of fatty acids in the microalgae may have toxic effects on rumen bacteria and microflora.

Calves were receptive to the taste of Chlorella sp. added to calf starter, and 1 of the 6 calves preferred the starter with $60 \mathrm{~g}$ of algae compared with the other starters. Calves tended to consume greater amounts of control calf starter than calf starter with Chlorella sp. It is possible that calves fed Chlorella sp. in the calf starter did not consume more because they disliked the taste of Chlorella $\mathrm{sp}$. in the rations. Therefore, feeding Chlorella sp. in calf starter to dairy calves may not be justified. Future research is needed to identify effects of long-term supplementation of Chlorella sp. in dairy cattle diets.

\section{References}

Altomonte, I., F. Salari, R. Licitra, and M. Martini. 2018. Use of microalgae in ruminant nutrition and implications on milk quality-A review. Livest. Sci. 214:25-35. https://doi.org/10.1016/j.livsci.2018.05.006.

AOAC International. 2016. Official Methods of Analysis. 20th ed. AOAC International, Gaithersburg, MD.

Campisano, R., K. Hall, J. Griggs, S. Willison, S. Reimer, H. Mash, M. Magnuson, L. Boczek, and A. N. D. E. Rhodes. 2017. Selected Analytical Methods for Environmental Remediation and Recovery (SAM). EPA/600/R-17/356, 2017. US Environmental Protection Agency, Washington, DC.

Chapman, C. E., R. G. Cabral, K. M. Aragona, and P. S. Erickson. 2016. Short communication: Cinnamaldehyde taste preferences of weaned dairy heifers. J. Dairy Sci. 99:3607-3611. https://doi.org/10.3168/jds.2015-10582.

Chowdhury, S. A., K. S. Huque, M. Khatunand, and Q. Nahar. 1995. Study on the use of algae as a substitute for oil cake for growing calves. Livest. Res. Rural Dev. 6:8-16. http://www.lrrd.org/lrrd6/3/2.htm.

Erickson, P. S., S. P. Marston, M. Gemmel, J. Deming, R. G. Cabral, M. R. Murphy, and J. I. Marden. 2012. Short communication: Kelp taste preferences by dairy calves. J. Dairy Sci. 95:856-858. https://doi.org/10.3168/ jds.2011-4826.

Görs, M., R. Schumann, D. Hepperle, and U. Karsten. 2010. Quality analysis of commercial Chlorella products used as dietary supplement in human nutrition. J. Appl. Phycol. 22:265-276. https://doi.org/10.1007/s10811-009 $-9455-4$.

Heins, B. J., and H. Chester-Jones. 2015. Effect of feeding kelp on growth and profitability of group-fed calves in an organic production system. Prof. Anim. Sci. 31:368-374. https://doi.org/10.15232/pas.2015-01390.

Jeon, J.-Y., K.-K. Park, K.-W. Lee, S.-W. Jang, B.-H. Moon, and B.-K. An. 2016. Dietary effects of lutein-fortified chlorella on milk components of Holstein cows. Springerplus 5:908. https://doi.org/10.1186/s40064-016 $-2622-6$.

Kienitz, M. J., B. J. Heins, and H. Chester-Jones. 2017. Growth, behavior, and economics of group-fed dairy calves fed once or twice daily in an organic production system. J. Dairy Sci. 100:3318-3325. https://doi.org/10.3168/ jds.2016-11885. 
Koller, M. 2015. Design of closed photobioreactors for algal cultivation. Pages 133-186 in Algal Biorefineries. A. Prokop, R. Bajpai, and M. Zappi, ed. Cham, Springer, Switzerland. https://doi.org/10.1007/978-3-319-20200-6 4.

Kotrbáček, V., J. Doubek, and J. Doucha. 2015. The chlorococcalean alga Chlorella in animal nutrition: A review. J. Appl. Phycol. 27:2173-2180. https:// doi.org/10.1007/s10811-014-0516-y.

Kuzmaite, I., V. Oberauskas, J. Kantautaitė, J. Žymantienè, R. Želvytė, I. Monkevičienè, A. Sederevičius, and B. Bakutis. 2009. The effect of Chlorella vulgaris IFR-111 on microflora of the digestive system of neonate calves. Vet. Zootech. 47:44-49.

Madeira, M. S., C. Cardoso, P. A. Lopes, D. Coelho, C. Afonso, N. M. Bandarra, and J. A. M. Prates. 2017. Microalgae as feed ingredients for livestock production and meat quality: A review. Livest. Sci. 205:111-121. https:// doi.org/10.1016/j.livsci.2017.09.020.

Makkar, H. P. S., G. Tran, V. Heuzé, S. Giger-Reverdin, M. Lessire, F. Lebas, and P. Ankers. 2016. Seaweeds for livestock diets: A review. Anim. Feed Sci. Technol. 212:1-17. https://doi.org/10.1016/j.anifeedsci.2015.09.018.

Nombekela, S. W., M. R. Murphy, H. W. Gonyou, and J. I. Marden. 1994. Dietary preferences in early lactation cows as affected by primary tastes and some common feed flavors. J. Dairy Sci. 77:2393-2399. https://doi.org/10 .3168/jds.S0022-0302(94)77182-4

SAS Institute. 2016. SAS/JMP Software. Release 14.3. SAS Institute Inc., Cary, NC.

Schimek, D., B. Ziegler, D. Ziegler, and H. Chester-Jones. 2016. Performance and health of calves pre- and post-weaning when fed milk replacer supplemented with algae. J. Anim. Sci. 94(Suppl 5):583-584. https://doi.org/10 .2527/jam2016-1215.

US EPA. 2014. Method 6010D (SW-846): Inductively coupled plasma-atomic emission spectrometry; revision 4. Environmental Protection Agency (EPA), Washington, DC

\section{Notes}

B. J. Heins (D) https://orcid.org/0000-0003-2186-9082

Funding for this project was provided by the Minnesota Environment and Natural Resources Trust Fund (St. Paul, MN) as recommended by the LegislativeCitizen Commission on Minnesota Resources (LCCMR).

The authors have not stated any conflicts of interest. 